\title{
SOEP
}

SOEPpapers

on Multidisciplinary Panel Data Research

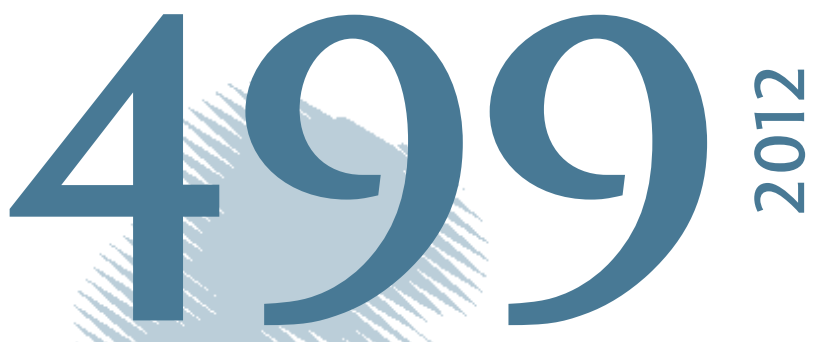

$\stackrel{N}{\sim}$

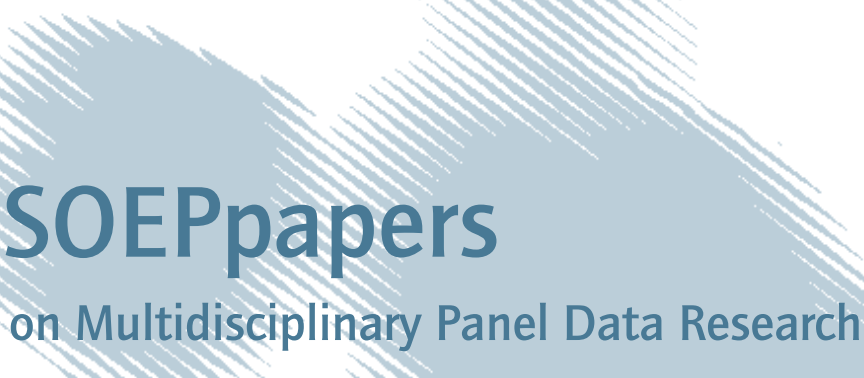

,
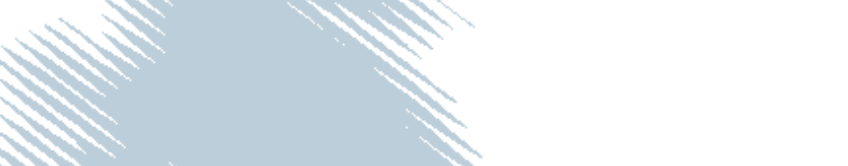

\section{Validating an Ultra-Short Survey Measure of Patience}




\section{SOEPpapers on Multidisciplinary Panel Data Research}

at DIW Berlin

This series presents research findings based either directly on data from the German SocioEconomic Panel Study (SOEP) or using SOEP data as part of an internationally comparable data set (e.g. CNEF, ECHP, LIS, LWS, CHER/PACO). SOEP is a truly multidisciplinary household panel study covering a wide range of social and behavioral sciences: economics, sociology, psychology, survey methodology, econometrics and applied statistics, educational science, political science, public health, behavioral genetics, demography, geography, and sport science.

The decision to publish a submission in SOEPpapers is made by a board of editors chosen by the DIW Berlin to represent the wide range of disciplines covered by SOEP. There is no external referee process and papers are either accepted or rejected without revision. Papers appear in this series as works in progress and may also appear elsewhere. They often represent preliminary studies and are circulated to encourage discussion. Citation of such a paper should account for its provisional character. A revised version may be requested from the author directly.

Any opinions expressed in this series are those of the author(s) and not those of DIW Berlin. Research disseminated by DIW Berlin may include views on public policy issues, but the institute itself takes no institutional policy positions.

The SOEPpapers are available at

http://www.diw.de/soeppapers

\section{Editors:}

Jürgen Schupp (Sociology, Vice Dean DIW Graduate Center)

Gert G. Wagner (Social Sciences)

Conchita D'Ambrosio (Public Economics)

Denis Gerstorf (Psychology, DIW Research Director)

Elke Holst (Gender Studies, DIW Research Director)

Frauke Kreuter (Survey Methodology, DIW Research Professor)

Martin Kroh (Political Science and Survey Methodology)

Frieder R. Lang (Psychology, DIW Research Professor)

Henning Lohmann (Sociology, DIW Research Professor)

Jörg-Peter Schräpler (Survey Methodology, DIW Research Professor)

Thomas Siedler (Empirical Economics)

C. Katharina Spieß (Empirical Economics and Educational Science)

ISSN: 1864-6689 (online)

German Socio-Economic Panel Study (SOEP)

DIW Berlin

Mohrenstrasse 58

10117 Berlin, Germany

Contact: Uta Rahmann | soeppapers@diw.de 


\title{
Validating an Ultra-Short Survey Measure of Patience
}

\author{
Thomas Vischer* Thomas Dohmen ${ }^{\dagger} \quad$ Armin Falk $^{\ddagger} \quad$ David Huffman $^{\S}$ \\ Jürgen Schupp $\quad$ Uwe Sundell Gert G. Wagner**
}

October 2, 2012

\begin{abstract}
This study presents results of the validation of an ultra-short survey measure of patience included in the German Socio-Economic Panel (SOEP). Survey responses predict intertemporal choice behavior in incentive-compatible decisions in a representative sample of the German adult population.
\end{abstract}

JEL-classification: D01, D03, D91, C91

Keywords: Time Preferences, Discounting, Validation of Survey Measures

\footnotetext{
${ }^{*}$ University of Munich

${ }^{\dagger}$ Maastricht University, IZA, Bonn, DIW Berlin

${ }^{\ddagger}$ University of Bonn, IZA, Bonn, CEPR, London, DIW Berlin

${ }^{\S}$ Swarthmore College, IZA, Bonn

"DIW Berlin, Free University of Berlin

"University of Munich, IZA, Bonn, CEPR, London, DIW Berlin

${ }^{* *}$ Max Planck Institute of Human Development, Berlin, DIW Berlin, Berlin University of Technology
} 


\section{Introduction}

Essentially all economic decisions involve a time dimension and thus a trade-off between payoffs or costs that accrue at different points in time. Patience (or the rate of time preference) is the central preference parameter that shapes such decisions over time. Accordingly, controlling for time preference (patience) is important in many economic applications.

So far, this has been prevented by the lack of a reliable measure of patience in large-scale representative surveys, since direct measures of patience are typically elicited in laboratory experiments among particular (student) subject pools only (see, e.g., Frederick et al., 2002, for a survey) 1 Indirect measures of patience are sometimes constructed from consumption and savings patterns (see, e.g., Hausman, 1979, Gourinchas and Parker, 2002.), but cannot remedy the non-existence of directly elicited measures of patience in large representative surveys. The obvious problem lies in the prohibitively high costs of conducting large scale experiments, which is why most experimental studies had to rely on comparably small samples that have been constructed specifically for the purpose of the experiment.

This note fills this gap by validating a survey measure of patience that has been included in a large and representative data set, the German Socio-Economic Panel Study (SOEP). The measure for patience is based on the responses to a question about "how patient in general" respondents are, expressed on a scale from 0 to 10. A representative sub-sample of respondents to this question has also participated in incentive-compatible intertemporal choice experiments. Relating the survey measure of patience to the experimental measure of patience allows for a validation along the lines of Dohmen et al. (2011a) who relate a survey measure of risk attitudes in a survey (SOEP) to choices in a lottery experiment. The results show that the responses to the survey question predict behavior in the intertemporal choice experiment. With this validated measure of patience, the SOEP offers abundant research opportunities on a wide range of interesting topics involving intertemporal choices.

\section{Data and Measures}

The analysis is based on a representative subsample of the German Socio-Economic Panel (SOEP). The SOEP is a representative household survey from the resident population of Ger-

\footnotetext{
${ }^{1}$ Few studies conducted experiments among other subject pools, including inhabitants of Vietnamese villages, see Tanaka et al. (2010) or children and adolescents, see Eckel et al. (2010) and Kocher et al. (2012). A notable exception is Harrison et al. (2002) and Andersen et al. (2008) who conduct time preference experiments with representative samples from Denmark.
} 
many over the age of 17 . The SOEP has been used extensively in empirical research 2

Time Preference Experiments The analysis is based on a representative sub-sample of respondents to the 2006-wave of the SOEP who participated in incentivized experiments to elicit time preferences 3 Table 1 contains a comparison of the sample composition in terms of gender, age and height, of the 2006-wave of the SOEP and the participants in the experiment.

In the experiment, 977 participants were asked to indicate their preferences in a choice over a 12-month time horizons $4^{4}$ The choice tables requested participants to indicate their preference between an immediate payment, or a delayed but larger payment to be received twelve months later. Participants faced this choice for 20 different sizes of the delayed payment. The immediate payment (depicted in the left column of the table) was a fixed amount of $€ 200$ (€1 $\sim$ US 1.30) in each choice situation, the respective delayed payment (in the right column) was increased by 2.5 percentage points (compounded semi-annually) from row to row. Once a respondent had switched from the smaller, immediate payment to the larger, delayed payment, the interviewer verified that the respondent also preferred the later payment in all subsequent rows. From this switch, it is possible to infer the rate of return required to induce the individual to wait for the delayed payment $5^{5}$ After the experiment, a random device determined the actual pay-off relevant choice decision. This procedure, which was explained before the start of the experiment, ensured that all decisions in the elicitation of time preferences were incentive compatible (see also Holt and Laury, 2002, who have used a similar procedure in the domain of risk preferences). A second random device determined which participants actually received the monetary equivalent corresponding to their choices, with a pay-out ratio of $1 / 9$ of all participants ${ }_{6}^{6}$ All participants that were drawn to receive a payment were sent a cheque. This cheque could be cashed immediately if the choice was the immediate payment, or in 12 months if the delayed payment had been chosen. Since the SOEP as well as the appointed fieldwork institute (TNS Infratest, Munich)

${ }^{2}$ See, e.g., Dohmen et al. (2011) or , as well as Wagner, Schupp, and Frick (2007) and TNS-Infratest-Sozialforschung (2011) for a detailed description.

${ }^{3}$ See Wagner, Schupp, and Frick (2007) for detailed information on the sampling procedure and formalities of collecting the data. Out of a representative sample of 1,548 individuals who were asked to participate in experimental treatments only $45(2.9 \%)$ refused to participate. As a consequence, a severe item non-response bias is rather unlikely.

${ }^{4}$ These decisions were the first choices in a series of experiments. This is important as the findings by Dohmen et al. (2012) indicate that intertemporal decisions in later choice tables over different time horizons are potentially affected by the time horizon of the first choice table. In addition, a time horizon of 12 months appears natural given that most interest rates are computed annually.

${ }^{5}$ In fact it is only possible to infer bounds on the discount rate. Accordingly, the empirical analysis is based on interval regressions.

${ }^{6}$ For 430 observations we observe their monthly net income in the month previous to the interview, which equals on average $€ 1581.42$. Hence, the minimum amount of $€ 200$ to be won is arguably a non-negligible fraction (12.6\%) of the monthly income and certainly higher than the stakes in typical laboratory experiments. See also Harrison (1992) and Manzini et al. (2008) for a discussion on the effects of stake sizes. 
enjoy excellent reputations, it is unlikely that credibility problems concerning payment affected the behavior ${ }^{7}$ Moreover, sending a cheque in both cases, for immediate and delayed payments, rules out that credibility concerns favor immediate payments (front-end delay).

A Survey Measure of Patience The 2008-wave of the SOEP contains a survey measure of impatience in terms of a question that asks respondents to indicate their general impatience. The exact wording of the question is: "Are you generally an impatient person, or someone who always shows great patience?". Answers are coded on an 11-point scale, with "0" referring to "very impatient" and "10" to "very patient" 8 The same wave of the SOEP also contains a question that asks participants to rate their personal impulsiveness on the same scale, with "0" refereing to "not at all impulsive" and "10" to "very impulsive", which provides the possibility to control for impulsiveness so to distinguish it from patience?

\section{Validation Results}

Participants in the experiment exhibit a considerable degree of impatience, with a mean of the implicit rate of return of 26.07 percent p.a., and a median of 25 percent, implying that the majority of the selected participants opted for and received $€ 200$ with immediate maturity. However, the data also show substantial heterogeneity in patience, as the standard deviation of the implicit rate of return amounts to 18.41 . While 12.38 percent of participants require an extra 25 percent p.a. in order be willing to wait for 12 months for the amount of $€ 200,13$ percent of participants are willing to wait for an annual return of 2.5 percent. On the other hand, 18.63 percent of the participants choose the immediate reward even when trading it off against a delayed reward that is 50 percent larger. The implied discount rates are remarkably similar to the results reported in Harrison et al. (2002, p. 1612), who elicit an average discount rate of $28 \%$ for their full sample of 268 Danish individuals.

To validate the general patience measure, we investigate whether the survey measure of impatience can predict actual behavior in the incentive-compatible time preference experiment. If it does, this justifies the use of the impatience measure as a relevant proxy for time preferences

\footnotetext{
${ }^{7}$ This point is reinforced by the fact that the sample population is familiar with these institutes due to their participation in previous waves.

${ }^{8}$ The original wording in German was: "Wie schätzen Sie sich persönlich ein: Sind Sie im allgemeinen ein Mensch, der ungeduldig ist, oder der immer sehr viel Geduld aufbringt? Bitte kreuzen Sie ein Kästchen auf der Skala an, wobei der Wert 0 bedeutet: "sehr ungeduldig", und der Wert 10: "sehr geduldig". Mit den Werten dazwischen können Sie Ihre Einschätzung abstufen."

${ }^{9}$ The distinction between impatience and impulsiveness is important, since impulsive behavior may mask the importance of general time attitudes, particularly in situations that involve stimuli that trigger an impulsive behavior, such as a pack of cigarettes in front of a recently turned non-smoker.
} 
in empirical applications based on the comprehensive SOEP. Notice that the experiment was conducted roughly two years before the survey question, minimizing problems of recall or induced responses.

Figure 1 shows the frequency distribution of the responses to the (reversed) question for the entire SOEP sample, as well as for the sample of experiment participants. The two distributions are not statistically different $\left(p=0.71\right.$, Kolmogorov-Smirnov) ${ }^{10}$

Table 2 shows the results of the validation exercise. In Column (1), the internal rate of return that corresponds to the switching row from immediate to delayed payments in the experiment is regressed on the hypothetical survey measure. The effect is positive and significant $(p<0.05)$, indicating that a higher degree of impatience predicts behavior in the experiment. In other words, individuals who state that they are more impatient in the survey in 2008 also exhibit a higher degree of impatience in the incentivized choice experiment in 2006. This evidence provides a validation of the behavioral relevance of the subjective impatience question. To exclude the possibility of the result being affected by unobserved heterogeneity, the following columns include additional controls. Column (2) includes the plausibly exogenous covariates gender, age, and height, with additional (potentially endogenous) controls in columns (3) and (4). Throughout all specifications, the coefficient estimate of the survey measure of impatience remains sizeable and highly significant, irrespective of the additional variables added to the model. In particular, the estimated coefficient on impatience preserves its predictive power even when including a control for impulsiveness, which can be taken as evidence for the validity of the hypothetical survey measure in capturing impatience, and not merely impulsiveness. This helps to rule out a spurious correlation based on the argument that respondents misconceive the question to ask for impulsive behavior, instead of general patience. Also, controlling for risk attitudes, as a proxy for the curvature of the utility function, appears not to affect the result 11 This mitigates the issue of omitted variable bias due to the omission of a relevant trait for the decision process.

In summary, the findings suggest that a simple and ultra-short, qualitative survey measure of patience represents a meaningful proxy for time preferences as elicited using the typical price list decision format. The distinct advantage of this qualitative survey measure is its ability to gather information on time preferences that is behaviorally relevant while at the same time cheap to elicit at a large and representative scale. This measure can be useful as control for

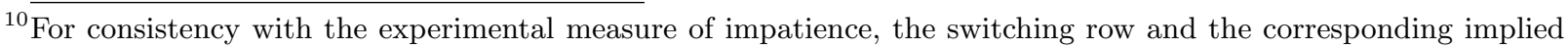
rate of return, which indicate higher impatience, the survey responses are reversed, from "0" referring to "very patient" to "10" - "very impatient".

${ }^{11}$ This control variable is potentially very important in the analysis of time preferences, see Andersen et al. (2008).
} 
patience in future applications. 


\section{References}

Andersen, S., G. W. Harrison, M. I. Lau, and M. B. Williams (2008): "Eliciting Risk and Time Preferences," Econometrica, 76(3), 583-618.

Dohmen, T., A. Falk, D. Huffman, and U. Sunde (2012): "Interpreting Time Horizon Effects in Inter-Temporal Choice," IZA Discussion Paper, 6385.

Dohmen, T., A. Falk, D. Huffman, U. Sunde, J. Schupp, and G. G. Wagner (2011): "Individual Risk Attitudes: New Evidence from a Large, Representative, ExperimentallyValidated Survey," Journal of the European Economic Association, 9(3), 522-550.

Eckel, C. C., P. J. Grossman, C. A. Johnson, A. De Oliveira, C. Rojas, and R. K. Wilson (2010): "(Im)Patience Among Adolescents: A Methodological Note," University of Dallas, available at $h t t p: / /$ ssrn.com/abstract $=1883745$.

Frederick, S., G. Loewenstein, and T. O'Donoghue (2002): "Time Discounting and Time Preference: A Critical Review," Journal of Economic Literature, 40(2), 351-401.

Gourinchas, P.-O., and J. A. Parker (2002): "Consumption Over the Life Cycle," Econometrica, 70(1), 49-89.

HARrison, G. W. (1992): "Theory and Misbehavior of First-Price Auctions: Reply," American Economic Review, 82(5), 1426-1443.

Harrison, G. W., M. I. Lau, and M. B. Williams (2002): "Estimating Individual Discount Rates in Denmark: A Field Experiment," American Economic Review, 92(5), 1606-1617.

Hausman, J. (1979): "Individual Discount Rates and the Purchase and Utilization of EnergyUsing Durables," Bell Journal of Economics, 10(1), 33-54.

Headey, B., R. Muffels, and G. G. Wagner (2010): "Long-Running German Panel Survey Shows That Personal and Economic Choices, Not Just Genes, Matter for Happiness," PNAS, Proceedings of the National Academy of Sciences, 107(42), 17922-17926.

Holt, C., And S. Laury (2002): "Risk Aversion and Incentive Effects," American Economic Review, 92(5), 1644-1655.

Kocher, M., D. Rützler, M. Sutter, and S. Trautmann (2012): "Impatience and Uncertainty: Experimental Decisions Predict Adolescents' Field Behavior," American Economic Review, forthcoming.

Manzini, P., M. Mariotti, And L. Mittone (2008): "The elicitation of time preferences," CEEL Working Paper, 6(08).

Tanaka, T., C. Camerer, and Q. Nguyen (2010): "Risk and Time Preferences: Linking Experimental and Household Survey Data from Vietnam," American Economic Review, 100(1), $557-571$.

TNS-Infratest-Sozialforschung (2011): "Methodenbericht zum Befragungsjahr 2006 (Welle 23) des Sozio-oekonomischen Panels," SOEP Survey Paper, 61.

Wagner, G. G., J. Schupp, and J. Frick (2007): "The German Socio-Economic Panel Study (SOEP) Scope, Evolution and Enhancements," Journal of Applied Social Science Studies, 127(1), 139-169. 
Table 1: Descriptive Statistics of Characteristics

\begin{tabular}{lcccccc}
\hline \hline & \multicolumn{7}{c}{ SOEP } & \multicolumn{3}{c}{ Field Experiment } \\
\cline { 2 - 6 } & $\begin{array}{c}\text { Mean } \\
(1)\end{array}$ & $\begin{array}{c}\text { Std. Dev. } \\
(2)\end{array}$ & $\begin{array}{c}\mathrm{N} \\
(3)\end{array}$ & $\begin{array}{c}\text { Mean } \\
(4)\end{array}$ & $\begin{array}{c}\text { Std. Dev. } \\
(5)\end{array}$ & $\begin{array}{c}\mathrm{N} \\
(6)\end{array}$ \\
\hline \hline Fraction Female & 0.524 & 0.499 & 22,358 & 0.515 & 0.500 & 977 \\
Age (in years) & 48.59 & 17.45 & 22,358 & 52.64 & 17.56 & 977 \\
Height (in cm) & 171.33 & 9.33 & 22,296 & 170.76 & 9.29 & 974 \\
\hline
\end{tabular}

Note: Columns (1)-(3) (SOEP) are based on the w-wave (2006).

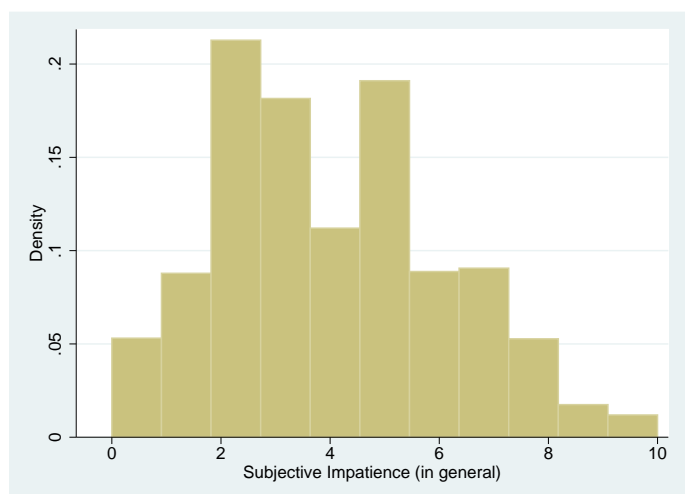

(a) Distribution of Subjective Impatience (SOEP)

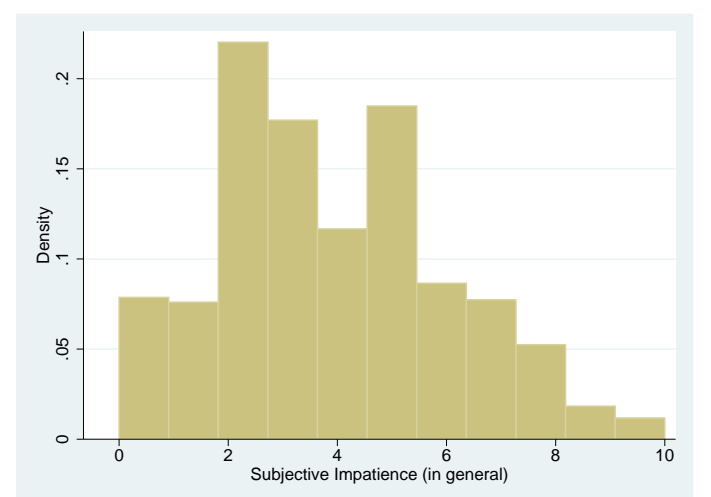

(b) Distribution of Subjective Impatience (Experiment Sample)

Figure 1: Distribution of Subjective Impatience 
Table 2: Validation Results

\begin{tabular}{|c|c|c|c|c|}
\hline & Dependent & Variable: & Internal Rate & of Return \\
\hline & (1) & $(2)$ & (3) & $(4)$ \\
\hline Impatience & $\begin{array}{c}0.758^{* *} \\
{[0.377]}\end{array}$ & $\begin{array}{c}0.849^{* *} \\
{[0.378]}\end{array}$ & $\begin{array}{c}0.849^{* *} \\
{[0.391]}\end{array}$ & $\begin{array}{c}1.060^{* *} \\
{[0.417]}\end{array}$ \\
\hline Female & & $\begin{array}{l}-0.067 \\
{[2.400]}\end{array}$ & $\begin{array}{c}{[0.391]} \\
0.817 \\
{[2.424]}\end{array}$ & $\begin{array}{c}{[0.609} \\
{[2.631]}\end{array}$ \\
\hline Age & & $\begin{array}{c}-1.112^{* * *} \\
{[0.298]}\end{array}$ & $\begin{array}{c}-0.760^{* *} \\
{[0.309]}\end{array}$ & $\begin{array}{c}-0.847^{* *} \\
{[0.389]}\end{array}$ \\
\hline Age Squared & & $\begin{array}{c}0.011^{* * *} \\
{[0.003]}\end{array}$ & $\begin{array}{l}0.007^{* *} \\
{[0.003]}\end{array}$ & $\begin{array}{c}0.008^{* *} \\
{[0.004]}\end{array}$ \\
\hline Height (in $\mathrm{cm}$ ) & & $\begin{array}{c}-0.217^{*} \\
{[0.127]}\end{array}$ & $\begin{array}{c}{[0.1} \\
-0.1 \\
{[0.133]}\end{array}$ & $\begin{array}{l}{[0.0096} \\
-0.096 \\
{[0.142]}\end{array}$ \\
\hline Parents Abitur & & & $\begin{array}{c}-6.342^{* *} \\
{[2.534]}\end{array}$ & $\begin{array}{c}-6.041^{*} * \\
{[2.722]}\end{array}$ \\
\hline Log Inc. 2006 & & & $\begin{array}{c}-5.506^{* * *} * \\
{[1.386]}\end{array}$ & $\begin{array}{c}-3.415^{* *} \\
{[1.635]}\end{array}$ \\
\hline Risk Attitudes & & & & $\begin{array}{c}-0.868^{* *} \\
{[0.420]}\end{array}$ \\
\hline Standardized IQ & & & & $\begin{array}{l}-0.109 \\
{[1.036]}\end{array}$ \\
\hline Impulsiveness & & & & $\begin{array}{l}-0.135 \\
{[0.468]}\end{array}$ \\
\hline Married (Living Together) & & & & $\begin{array}{c}1.241 \\
{[2.613]}\end{array}$ \\
\hline Widowed & & & & $\begin{array}{c}6.03 \\
{[4.116]}\end{array}$ \\
\hline Foreign Nationality & & & & $\begin{array}{l}7.665^{*} \\
{[3.948]}\end{array}$ \\
\hline Registered Unemployed & & & & $\begin{array}{c}9.632 * * * \\
{[3.650]}\end{array}$ \\
\hline Christian Denomination & & & & $\begin{array}{l}-2.976 \\
{[2.091]}\end{array}$ \\
\hline White Collar Worker & & & & $\begin{array}{l}-1.443 \\
{[2.355]}\end{array}$ \\
\hline Civil Servant & & & & $\begin{array}{l}-4.833 \\
{[4.321]}\end{array}$ \\
\hline No. of Children & & & & $\begin{array}{c}0.792 \\
{[0.857]}\end{array}$ \\
\hline Constant & $\begin{array}{c}22.355^{* * *} * \\
{[1.750]}\end{array}$ & $\begin{array}{c}83.620^{* * *} * \\
{[23.796]}\end{array}$ & $\begin{array}{c}113.512^{* * *} \\
{[25.754]}\end{array}$ & $\begin{array}{c}97.033^{* * *} * \\
{[29.530]}\end{array}$ \\
\hline Log Sigma & $\begin{array}{c}3.183^{* * *} * \\
{[0.031]}\end{array}$ & $\begin{array}{c}3.168^{* * *} * \\
{[0.031]}\end{array}$ & $\begin{array}{c}3.126^{* * *} * \\
{[0.032]}\end{array}$ & $\begin{array}{c}3.049 * * * \\
{[0.036]}\end{array}$ \\
\hline Log Pseudo-Likelihood & -2426 & -2415 & -2152 & -1690 \\
\hline Observations & 839 & 839 & 748 & 586 \\
\hline
\end{tabular}

Results from Interval regressions. Individuals who always preferred the larger, later option are treated as censored from below. Individuals who never preferred the larger, later option are treated as censored from above. Robust standard the larger, later option are treated as censored from above. Robust standard errors in brackets.
respectively. The original "Patience" question from the y-wave of the SOEP has respectively. The original "Patience" question from the y-wave of the SOEP has
been inverted. Accordingly, higher values indicate higher levels of impatience. 